\title{
Prevalence of Dental Caries in Children
}

\author{
Dr. Muhammad Alam Sikder ${ }^{1 *}$, Dr. Tasneem Faruqui ${ }^{2}$, Dr. KM Abdullah Al Harun ${ }^{3}$, \\ Dr. Sajjad Mahmud ${ }^{4}$, Dr. Radia faruqui ${ }^{5}$
}

\section{AFFILIATION:}

1. Assistant Professor and Head,

Science of Dental Materials,

Dental Unit, Sylhet MAG Osmani Medical College, Sylhet. Bangladesh.

2. Lecturer (Honorary), Dental Unit,

Sylhet MAG Osmani Medical College, Sylhet, Bangladesh.

E-mail: drtasneemfaruqui666@gmail.com, Mobile: 01717022085

3. Lecturer, Dept. of Dental Public Health, Dental Unit,

Sylhet MAG Osmani Medical College, Sylhet, Bangladesh.

E-mail : romeoddc@gmail.com Mobile: 01711488167.

4. FCPS (Medicine) Trainee,

Sylhet MAG Osmani Medical College Hospital,

Sylhet, Bangladesh. Mobile: 01743044109

5. Lecturer, Dept. Of Pathology,

Sylhet Women's Medical College and Hospital,

Sylhet. Bangladesh. Mobile: 01671648521

\section{Article info.}

Received: 15 November 2020

Accepted: 23 December 2020

Volume: Vol-11, Issue-1, April 2021

DOI: https://doi.org/10.3329/updcj.v11i1.53000

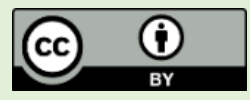

(C) Authors retain copyright and grant the journal right of first publication with the work simultaneously licensed under Creative Commons Attribution License CC - BY 4.0 that allows others to share the work with an acknowledgment of the work's authorship and initial publication in this journal.

https://creativecommons.org/licenses/by/4.0/

Publisher: Update Dental College, Dhaka, Bangladesh

Web: www.updatedentalcollege.edu.bd

E-mail: updcj@hotmail.com

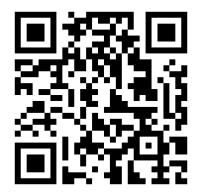

Scan QR code to see the latest issue

* Corresponding Author

Dr. Muhammad Alam Sikder

Assistant Professor and Head,

Science of Dental Materials,

Dental Unit, Sylhet MAG Osmani Medical College,

Sylhet. Bangladesh.

E-mail: alamdr8@gmail.com

Cell Phone : +8801712604174

\section{ABSTRACT:}

This cross sectional study on oral condition among school going children in Sylhet city was conducted at Osmani Medical High School, Dorgah Gate, Sylhet, Bangladesh. This study was carried out on $8^{\text {th }}$ October, 2019 among 208 students, mostly 12 years aged studying in Class VI. The main objective of the study was to assess the oral health condition of school going children through decayed, missing, and filled teeth (DMFT) status. Data was collected by personal interview and clinical examination of the respondents. Among 208 children, 96 (46.2\%) were boys and $112(53.8 \%)$ were girls. Among all, 63 (30.3\%) respondents brush their teeth once daily while 137 (65.9\%) respondents brush twice a day, and $8(3.8 \%)$ of them brush their teeth more than twice daily. Fluoride containing toothpaste is used by $73(35.1 \%)$ students, $112(53.8 \%)$ students did not know whether their toothpaste contain fluoride or not, and 23 (11.1\%) students do not use fluoride. Among all respondents, $125(60.09 \%)$ did not have any decayed tooth, while 83(39.90 $\%)$ had tooth decay, and 20(9.6\%) had their teeth filled. Normal gingival condition was found in $185(88.94 \%)$ subjects, but 23(11.06 \%) of them had red or swollen gingiva. The mean DMFT of the study population was 1.19 which is considered as "low" according to "WHO quantification for the DMFT index".

\section{KEYWORDS:}

\section{INTRODUCTION:}

One of the essential components of general wellbeing is good oral health. Oral health status in developed countries children's are improving over the last few decades, One of the important parameters of oral health status in developing countries caries incidence, , is increasing markedly due to changing life-styles and dietary patterns..$^{1,2,3}$ According to World Health Organization (WHO), the most common global health burden are dental caries and periodontal disorders and most widespread chronic diseases of the modern era. ${ }^{4,5}$ The world oral health report 2003 revealed that in Asian countries $60-90 \%$ of school going children were dental caries affected. Increase the rate of school absenteeism significantly and decrease the rate of homework completion due to Poor oral health and untreated dental conditions . $., 7,8$ It also imposes negative impact on the quality of life of children and adults. ${ }^{9}$ Proper oral health education including knowledge on maintaining oral hygiene, impact of sugar consumption and role of preventive and restorative dental health service etc. at school level plays an important role to improve the oral health status as well as quality of life of the future generation. ${ }^{10}$

The oral health status can be simply examined by "Decayed, Missing, Filled Teeth index (DMFT index)" and the state of gingiva (color and condition of gum tissue). The DMFT index, first developed by Klein, Palmer and Knutson in 1938 and modified by WHO, was created to express caries experience. The $D$ component is for untreated caries, $\mathrm{M}$ for missing teeth due to caries, and $\mathrm{F}$ for filling (dental restorations for caries treatment). The T means index per tooth. The WHO recommended protocol for oral health surveys is based only on clinical examinations. ${ }^{11}$

One of the major contributors to maintain good oral health is self care practice. ${ }^{12}$ This study focus on collecting data on the teeth cleaning pattern and the materials used for that purpose along with data on DMFT index and gingival condition to assess the oral health status of the participators. Since these data among school going children in 
Sylhet city are scarce and important for future dental public health planning, this study will provide important resource to the dental public health experts to make recommendations to the policy makers. METHODOLOGY

This descriptive type of cross-sectional study was carried out at Osmani Medical High School, Dorgah Gate, Sylhet, on $8^{\text {th }}$ October, 2019among 208 students aged average 12 years studying in Class VI. Sampling was done by convenient sampling technique. Data was collected by direct personal interview and clinical examination of the respondent students.

RESULTS:

Total 208 students, comprising of 96(46.2\%) boys and 112(53.8\%) girls, of Osmani Medical High School, Dorgah Gate, Sylhet, participated in the study. The age of the respondents ranged from 11 to 14 years. (Table-1).

Table 1: Socio-demographic and educational characteristics of respondents. Age of the respondents (In years)

11-12

$13-14$ Frequency Percentage

Gender of the respondents

Boy

Girl

Educational level of the respondents

Class VI

\begin{tabular}{|c|c|}
\hline 182 & $87.5 \%$ \\
\hline 26 & $12.5 \%$ \\
\hline 96 & $46.2 \%$ \\
\hline 112 & $53.8 \%$ \\
\hline & \\
\hline & 108 \\
\hline
\end{tabular}

Table-2 shows, 198 (95.19\%) of the respondents use tooth paste as their teeth cleaning material, but a large number of the students, $112(53.8 \%)$ don't know whether their teeth cleaning material contain Fluoride or not. Majority of the student brush twice or more a day.

Table 2.1: Frequency of teeth cleaning.

Tooth brushing frequency Characteristics

Once daily

Twice daily

More than twice

$\begin{array}{cc}\text { Frequency } & \text { Percentage } \\ 63 & 30.3 \% \\ 137 & 65.9 \% \\ 8 & 3.8 \%\end{array}$

Table 2.2 : Materials of teeth cleaning.

$\begin{array}{lcc}\text { Materials used for teeth cleaning } & \text { Frequency } & \text { Percentage } \\ \text { Tooth paste } & 198 & 95.19 \% \\ \text { Tooth powder } & 8 & 3.86 \% \\ \text { Miswak } & 2 & 0.96 \%\end{array}$

Table 2.3 : Use of Fluoride containing toothpaste/Powder.

$\begin{array}{lcc}\text { Tooth paste/powder containing fluoride } & \text { Frequency } & \text { Percentage } \\ \text { Yes } & 73 & 35.1 \% \\ \text { No } & 23 & 11.1 \% \\ \text { Don't know } & 112 & 53.8 \%\end{array}$

Table 2.4 : Time of tooth brushing. Characteristics

$$
\text { Frequency }
$$

\section{Percentage}

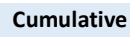

Before Breakfast

After Breakfast

After Dinner

Before Breakfast and

After Dinner

After Breakfast and

After Dinner

Before Breakfast and

After Breakfast

Before Breakfast,

After Breakfast and After

Dinner

$\begin{array}{ccc}63 & 30.3 \% & \begin{array}{c}\text { Percentage } \\ 30.3 \%\end{array} \\ 20 & 9.6 \% & 39.9 \% \\ 2 & 1.0 \% & 40.9 \% \\ 94 & 45.2 \% & 86.1 \% \\ 24 & 11.5 \% & 97.6 \% \\ 2 & 1.0 \% & 98.6 \% \\ 3 & 1.4 \% & 100 \%\end{array}$

About 83 (39.90\%) of the respondents had one or more teeth affected by dental caries. 9 (4.3\%) of the participants lost one or more of their teeth due to caries and 20 (9.62 \%) of them having at least one of their teeth filled at the time of the survey. The overall gingival

5 | P a g e status of the participant were good, only $23(11.05 \%)$ of them were found having red/swollen gum during the survey (Table-3).

$\begin{array}{lcc}\begin{array}{l}\text { Table } 3 \text { : Frequency distribution of oral examination of the respondents } \\ \text { Characteristics }\end{array} & \begin{array}{c}\text { Frequency } \\ \text { Percentage }\end{array} \\ \begin{array}{l}\text { Number of decayed teeth of the } \\ \text { respondents }\end{array} & 125 & 60.10 \% \\ 0 & 38 & 18.27 \% \\ 1 & 24 & 11.54 \% \\ 2 & 14 & 6.73 \% \\ 3 & 7 & 3.36 \% \\ 4 & & \\ \text { Number of Missing teeth of the } & 199 & 95.67 \% \\ \text { respondents } & 7 & 3.36 \% \\ 0 & 2 & 0.96 \% \\ 1 & & \\ 2 & 188 & 90.38 \% \\ \text { Number of filled teeth of the respondents } & 11 & 5.29 \% \\ 0 & 7 & 3.36 \% \\ 1 & 2 & 0.96 \% \\ 2 & & \\ \text { More than 2 } & 185 & 88.94 \% \\ \text { Gingival condition of the respondents } & 23 & 11.05 \% \\ \text { Normal/Healthy } & & \end{array}$

Table 4 shows, the mean DMFT found in this study was 1.19, which is "LOW" according to the quantification of the severity of dental caries defined by WHO parameters, 1986.

Table 4.1 : Distribution of respondents by decayed, Missing, Filled teeth and DMFT

\begin{tabular}{lcc} 
& DMFT & Frequency \\
Decayed & & 83 \\
Missing & & 09 \\
Filled & & 20 \\
DMFT & & 247.5 \\
Mean DMFT & & 1.19 \\
\multicolumn{1}{c}{ DMFT } & Frequency & \\
No cavity & 125 & Percentage (\%) \\
Decayed & 83 & $60.09 \%$ \\
Missing & 09 & $39.8 \%$ \\
filled & 20 & $4.3 \%$ \\
& & $9.6 \%$
\end{tabular}

\section{DISCUSSION:}

This study found more than $53.1 \%$ of the participant students were having either decayed or filled or missing teeth due to caries, which is bellow $90 \%$ found in school going children in Asian countries documented in The world oral health report 2003. ${ }^{7}$

Almost all students (95.19\%) use toothpaste as their teeth cleaning aid, which is similar, more than $90 \%$, found among Malaysian adults aged 15 years. ${ }^{13}$ Similar figures were found in most of the European countries and in Canada as well. ${ }^{14}$ Though the percentage is very high, it is not surprising as emphasis to use toothpaste for brushing is provided in school education and also in all electronic media, and it is easily available and cheap in Sylhet city. Better socio-economic status compared to rural population also acts as a booster to maintain this practice.

More than $69 \%$ students brush twice or more times daily, which is in consistent with the children in Sweden, Denmark, Germany, Austria, and Norway. ${ }^{14}$ Formation of dental plaque can be prevented if tooth brushing is practiced thoroughly at regular intervals and brushing twice a day is recommended by most of the dental experts to control bacterial plaque.$^{15}$ The study reveals that brushing twice a day becomes the common pattern of teeth cleaning and a norm among students.

Though most of the students use toothpaste and brush twice daily,

Website: https://www.banglajol.info/index.php/UpDCJ 
more than $53.80 \%$ of them don't know whether their toothpaste/toothpowder contains fluoride or not. Since the use of Fluoride is recognized as the most successful measures for caries prevention, improvement of knowledge on fluoridation can play a positive role. ${ }^{16}$

In this study around $11.05 \%$ students have swollen or red gum which indicates moderate to severe gingivitis. In UAE and in rural India it was found $20 \%$ and $25 \%$ respectively. ${ }^{17,18}$ Proper scoring, however, could increase the rate of moderate to severe gingivitis among school going children in Sylhet city.

Mean DMFT found in this study was 1.19 which is considered as "Low" according to the quantification of the severity of dental caries defined by WHO parameters, 1986. In Asia, the prevalence of dental caries in children is reported to be low to moderate as well. ${ }^{19}$ Decayed teeth contribute to the majority of the mean DMFT score (1.53 out of 1.19) which is in consistent with other studies. ${ }^{10,} 11$ Large number of decayed teeth, that is, untreated caries among school going children indicates inadequate access to the oral health service and lack of awareness among the parents which can lead to teeth loss and other dental diseases in future.

CONCLUSION:

Though the mean DMFT among school going children in Sylhet city is low and the overall gingival condition is good, the high rate of decayed or untreated caries indicates lack of awareness among the parents and also pointing towards the insufficiency of oral health service of that region. These issues need to be addressed as early possible to ensure general wellbeing and improve the quality of life. The teeth cleaning pattern, brushing twice a day with toothpaste, of the study population is well accepted. But lack of knowledge on fluoride could end up increasing caries incidence in future. Adequate fluoridation of drinking water, availability of fluoride containing toothpaste etc. are needed to be ensured to decrease the incidence of dental caries.

LIMITATION OF THE STUDY:

The findings of the study were discussed and interpreted considering several limitations including convenient sampling without randomization which in turn may not reflect the status of the target population leading to the chance of drawing biased information from the sample.

CONFLICT OF INTEREST : Author declared no conflict of interest

\section{REFERENCES:}

1. Marthaler TM, O'Mullane DM, Vrbic V. The prevalence of dental caries in Europe 1990-1995. ORCA Saturday afternoon symposium 1995. Caries research. 1996;30(4):237-55

https://doi.org/10.1159/000262332

PMid:8773416

2. Burt BA. Trends in caries prevalence in North American children. International dental journal. 1994;44(4 Suppl 1):403-13.

3. Rao A, Sequeira S, Peter S. Prevalence of dental caries among school children of Moodbidri. Journal of the Indian Society of Pedodontics and Preventive Dentistry. 1999;17(2):45-8.

4. Du M, Li Z, Jiang $\mathrm{H}$, Wang $\mathrm{X}$, Feng $\mathrm{X}, \mathrm{Hu} \mathrm{Y}$, et al. Dental Caries Status and its Associated Factors among 3-to 5-year-old Children in China: A National Survey. The Chinese journal of dental research: the official journal of the Scientific Section of the Chinese Stomatological Association (CSA). 2018;21(3):167-79.

5. THE CHALLENGE OF ORAL DISEASE "A call for global action" Available from: https://www.fdiworlddental.org/sites/default/files/media/documents/complete oh atlas.pdf.
6. Gopalan T, Asokan S, John JB, Geetha Priya PR. School absenteeism, academic performance, and self-esteem as proxy measures of oral health status: A crosssectional study. Journal of the Indian Society of Pedodontics and Preventive Dentistry. 2018;36(4):339-46.

https://doi.org/10.4103/JISPPD.JISPPD 21718

PMid:30324922

7. Petersen PE. The World Oral Health Report 2003: continuous improvement of oral health in the 21st century--the approach of the WHO Global Oral Health Programme. Community dentistry and oral epidemiology. 2003;31 Suppl 1:3-23. https://doi.org/10.1046/j..2003.com122.x PMid:15015736

8. Organization WH. Oral health promotion through Schools. WHO information series on school health. Document 11. Geneva: World Health Organization, in press 2003. Ref: WHO. NMH/NPH/ORH/School/03.3.

9. Jürgensen $\mathrm{N}$, Petersen $\mathrm{PE}$. Oral health and the impact of socio-behavioural factors in a cross sectional survey of 12 -year old school children in Laos. BMC oral health. 2009;9(1):29.

https://doi.org/10.1186/1472-6831-9-29 PMid:19917089 PMCid:PMC2781791

10. Bratthall $D$, Hansel-Petersson $G$, Sundberg $H$. Reasons for the caries decline: what do the experts believe? European journal of oral sciences. 1996;104(4 ( Pt 2)):41622; discussion 23-5, 30-2. https://doi.org/10.1111/j.1600-0722.1996.tb00104.x PMid:8930592

11. Organization WH. Oral health surveys: basic methods: World Health Organization; 2013.

12. https://www.who.int/oral health/action/information/surveillance/en/.

13. Esa R, Razak I, Jallaudin R, Jaafar $N$. A survey on oral hygiene practices among Malaysian adults. Clinical preventive dentistry. 1992;14(1):23-7.

14. Kuusela S, Honkala E, Kannas L, Tynjala J, Wold B. Oral hygiene habits of 11-yearold schoolchildren in 22 European countries and Canada in 1993/1994. Journal of Dental Research. 1997;76(9):1602-9. https://doi.org/10.1177/00220345970760091301 PMid:9294495

15. Löe $\mathrm{H}$. Oral hygiene in the prevention of caries and periodontal disease International dental journal. 2000;50(3):129-39. https://doi.org/10.1111/i.1875-595X.2000.tb00553.x PMid:10967765

16. Shekar C, Cheluvaiah MB, Namile D. Prevalence of dental caries and dental fluorosis among 12 and 15 years old school children in relation to fluoride concentration in drinking water in an endemic fluoride belt of Andhra Pradesh. Indian journal of public health. 2012;56(2):122-8

https://doi.org/10.4103/0019-557X.99902 PMid:22910620

17. Gopinath VK, Rahman B, Awad MA. Assessment of gingival health among school children in Sharjah, United Arab Emirates. European journal of dentistry. 2015;9(1):36. https://doi.org/10.4103/1305-7456.149636 PMid:25713482 PMCid:PMC4319297

18. Dhar V, Jain A, Van Dyke T, Kohli A. Prevalence of gingival diseases, malocclusion and fluorosis in school-going children of rural areas in Udaipur district. Journal of Indian Society of Pedodontics and Preventive Dentistry. 2007;25(2):103. https://doi.org/10.4103/0970-4388.33458 PMid:17660647

19. Nithila A, Bourgeois D, Barmes D, Murtomaa H. WHO Global Oral Data Bank, 198696: an overview of oral health surveys at 12 years of age. Bulletin of the World Health Organization. 1998;76(3):237.

To submit your manuscript, Mail us to : updci@hotmail.com

To see our latest issue, click the following link

https://www.banglajol.info/index.php/UpDCJ

Website: https://www.banglajol.info/index.php/UpDCJ 